\title{
Path Analysis on the Effects of Peer Support and Sanitation Facilities on Personal Hygiene among Female Student having Menstruation in Sragen Central Java
}

\author{
Kunaryanti'), Uki Retno Budihastuti²), Yulia Lanti Retno Dewi3) \\ 1)Masters Program in Public Health, Universitas Sebelas Maret, Surakarta \\ 2)Department of Obstetrics and Gynecology, Dr. Moewardi Hospital, Surakarta \\ 3) Faculty of Medicine, Universitas Sebelas Maret, Surakarta
}

\begin{abstract}
Background: Poor personal hygiene during menstruation causes the risk of Reproductive Tract Infection (RTI) in adolescent. It threatens women's health. Personal hygiene is affected by attitude, peer support, and the availability of personal hygiene facilities. This study aims to analyze the determinant of personal hygiene in adolescents during menstruation in Sragen Regency, Central Java.

Subjects and Method: This study was an analytic observational study with a cross sectional design. The study was conducted in June 2019. A sample of 200 study subjects was selected for this study by simple random sampling. The dependent variable was personal hygiene. The independent variables were attitude, peer support, and the availability of personal hygiene facilities. The study was collected by questionnaire and analyzed by path analysis.

Results: Personal hygiene was directly and positively affected by positive attitude $(b=1.38 ; 95 \%$ $\mathrm{CI}=0.78$ to $1.98 ; \mathrm{p}<0.001)$. Personal hygiene was indirectly affected by strong peer support and the availability of good personal hygiene facility.

Conclussion: Personal hygiene is directly and positively affected by positive attitude. Personal hygiene is indirectly affected by strong peer support and the availability of good personal hygiene facility.
\end{abstract}

Keywords: personal hygiene, attitude, peer support, personal hygiene facilities

\section{Correspondence:}

Kunaryanti. Masters Program in Public Health, Universitas Sebelas Maret, Jl. Ir. Sutami 36A, Surakarta 57126, Central Java. Email: kunaryanti@yahoo.com. Mobile: +6285700900029.

\section{BACKGROUND}

The practice of maintaining personal hygiene during menstruation is an important behavior in health, especially in female adolescents (Tiwari et al., 2018). Poor menstrual hygiene practice causes the risk of Reproductive Tract Infection (RTI) in an adolescent by 1.4 to 2.07 times (Sumpter and Torondel, 2013). Reproductive Tract Infection (RTI) is a silent epidemic that threatens women's health in the world. Every year, there are about 10\% of women worldwide affected by genital infection including urinary tract infection and bacterial vaginosis. The common risk factors for vaginal infection are pregnancy and poor hygiene especially bad behavior during menstruation (Das et al., 2015; Fehintola et al., 2017; Geethu et al., 2017).

Personal hygiene during menstruation is affected by several factors such as age, family support, knowledge, attitude, belief in myths, information exposure, access to places, water sanitation facilities, availability of personal hygiene facilities, socioeconomic status namely family income, privacy, and comfort in maintaining hygiene during menstruation. Another factor such as the source of information about menstruation can be obtained from 
parents, school, friends, and the mass media (Deshpande et al., 2018; Das, et al., 2015). The main factor that is dominant towards personal hygiene behavior during menstruation is peer support. They feel free to talk about anything that is considered private with peers. Therefore, peers have a big influence on hygiene behavior during menstruation (Eijk et al., 2016).

Based on the result of interview conducted by the researcher on ten female adolescents in Sragen regency, three female adolescents were able to mention how to take care of personal hygiene during menstruation and seven people were not able to mention how to take care of personal hygiene during menstruation, either changing pads, how to clean or wash genitals. The minimum information about personal hygiene care during menstruation caused complaint of symptoms of infection such as inflammation of the genital area, irritation, itching, and pain. Various factors prove that adolescents who have bad behavior in personal hygiene during menstruation is still high. Based on the background description, the researcher was interested in investigating and knowing more about the determinants of personal hygiene in adolescents during menstruation in Sragen Regency.

\footnotetext{
SUBJECTS AND METHOD

\section{Study Design}

This was an observational analytic study with a cross sectional design. This study was conducted in Sragen Regency, Central Java, in June 2019.
}

\section{Population and Sample}

The source population of the study was all female adolescents from Senior and Vocational High School in Sragen Regency. There were 200 study subjects involved as the sample of the study. They were selected by simple random sampling.

\section{Study Variables}

The dependent variable was personal hygiene. The independent variables were attitude, peer support, and the availability of personal hygiene facilities.

\section{Operational Definition of Variables Personal hygiene during menstrua- tion was all actions of female adolescents in taking care and maintaining hygiene on female external genital organs during men- struation. The data were collected by questionnaire. The measurement scale was continous, and transformed into dichoto- mous.}

Attitude was the response of a female adolescent in the form of positive or negative assessment in conducting or responding to personal hygiene during menstruation. The data were collected by questionnaire. The measurement scale was continous, and transformed into dichotomous.

Peer support was the encouragement from peers (school friends, playmates) that affected a female adolescent in conducting personal hygiene during menstruation. The data were collected by questionnaire. The measurement scale was continous, and transformed into dichotomous.

\section{Availability of personal hygiene faci-} lity was the availability of facilities and personal hygiene equipment needed by a female adolescent during menstruation. The data were collected by questionnaire. The measurement scale was continous, and transformed into dichotomous.

\section{Data Analysis}

Univariate analysis aimed to examine the frequency distribution and percentage of the characteristics of the study subjects. Bivariate analysis aimed to investigate the correlation between personal hygiene and the independent variables using chi-square. Multivariate analysis used path analysis with Stata 13. There were 5 stages of path analysis such as model specification, model 
identification, model suitability, parameter estimation, and model respesification.

\section{Research Ethics}

Research ethics consisted of informed consent form, anonymity, confidentiality, and ethical clearance. Ethical clearance in this study came from the Research Ethics Committee of Faculty of Medicine, Universitas

\section{Table 1. Sample Characteristic}

\begin{tabular}{|c|c|c|c|}
\hline Characteristic & & Frequency (n) & Percentage (\%) \\
\hline \multicolumn{4}{|l|}{ Age } \\
\hline$<16$ years & & 62 & 31.0 \\
\hline$\geq 16$ years & & 138 & 69.0 \\
\hline \multicolumn{4}{|l|}{ Class } \\
\hline Class 1 & & 93 & 46.5 \\
\hline Class 2 & & 107 & 53.5 \\
\hline \multicolumn{4}{|l|}{ Attitude } \\
\hline Negative & & 79 & 39.5 \\
\hline Positive & & 121 & 60.5 \\
\hline \multicolumn{4}{|l|}{ Peer Support } \\
\hline Weak & & 70 & 35.0 \\
\hline Strong & & 130 & 65.0 \\
\hline $\begin{array}{l}\text { Availability of Personal } \\
\text { Facilities }\end{array}$ & Hygiene & & \\
\hline Poor & & 65 & 32.5 \\
\hline Good & & 135 & 67.5 \\
\hline \multicolumn{4}{|l|}{ Personal Hygiene } \\
\hline Poor & & 82 & 41.0 \\
\hline Good & & 118 & 59.0 \\
\hline
\end{tabular}

Table 1 shows that the highest frequencies were the subjects aged $\geq 16$ years that were 138 subjects (69.0\%), subjects in class 2 that were 107 subjects (53.5\%), positive attitude of female adolescents that were 121 subjects (60.5\%), strong peer support that were 130 subjects (65.0\%), good availability of personal hygiene facilities that were 135 subjects (67.5\%), and good personal hygiene that were 118 subjects (59.0\%).

\section{Bivariate Analysis}

Table 2 showed the results of bivariate analysis. Table 2 showed that positive attitude $(\mathrm{OR}=3.96 ; \mathrm{p}<0.001)$, strong peer support $(\mathrm{OR}=6.16 ; \mathrm{p}<0.001)$, and the availability of good personal hygiene facilities $(\mathrm{OR}=$ 2.91; p <0.001) increased good personal hygiene.
Sebelas Maret, Surakarta, Number: 345/UN27.06/ KEPK/EC/2019.

$\frac{\text { RESULTS }}{\text { 1. Sample Characteristics }}$
Sample characteristic was showed in Table
1.

118

\section{Path Analysis}

Figure 1 shows the structural model after conducting the estimation using Stata 13. Table 3 shows that there was a direct and positive effect of attitude on personal hygiene; it was statistically significant. Female adolescents with positive attitude had a logodd of having personal hygiene by 1.38 units higher than female adolescents with negative attitude $(b=1.38 ; 95 \% \mathrm{CI}=0.77$ to 1.98; $\mathrm{p}<0.001)$. There was an indirect and positive effect of peer support on personal hygiene through attitude; the result was statistically significant. Female adolescents with strong peer support had a logodd of having positive attitude by 1.52 units higher than female adolescents with weak peer 
support $(b=1.52 ; 95 \% C I=0.88$ to -2.17 ; $\mathrm{p}<0.001)$.

There was an indirect and positive effect of the availability of personal hygiene facilities on personal hygiene through attitude; the result was statistically significant.
Female adolescent with good availability of personal hygiene facilities had a logodd of having positive attitude by 1.17 units higher than female adolescents with poor availability of personal hygiene facilities $(b=1.17$; $95 \% \mathrm{CI}=0.51$ to $2.17 ; \mathrm{p}<0.001$ ).

Table 2. Bivariate Analysis

\begin{tabular}{|c|c|c|c|c|c|c|c|c|}
\hline \multirow{3}{*}{ Independent Variable } & \multicolumn{4}{|c|}{ Personal Hygine } & \multirow{2}{*}{\multicolumn{2}{|c|}{ Total }} & \multirow{3}{*}{$\mathbf{O R}$} & \multirow{3}{*}{$\mathbf{p}$} \\
\hline & \multicolumn{2}{|c|}{ Poor } & \multicolumn{2}{|c|}{ Good } & & & & \\
\hline & $\mathbf{N}$ & $\%$ & $\mathbf{N}$ & $\%$ & $\mathbf{N}$ & $\%$ & & \\
\hline \multicolumn{9}{|l|}{ Attitude } \\
\hline Negative & 48 & 60.8 & 31 & 39.2 & 79 & 100 & 3.96 & $<0.001$ \\
\hline Positive & 34 & 28.1 & 87 & 71.9 & 121 & 100 & & \\
\hline \multicolumn{9}{|l|}{ Peer Support } \\
\hline Weak & 48 & 68.6 & 22 & 31.4 & 70 & 100 & 6.16 & $<0.001$ \\
\hline Strong & 34 & 26.2 & 96 & 73.8 & 130 & 100 & & \\
\hline \multicolumn{9}{|l|}{ Availability of Hygiene } \\
\hline Facilities & & & & & & & & \\
\hline Poor & 38 & 58.5 & 27 & 41.5 & 65 & 100 & 2.91 & $<0.001$ \\
\hline Good & 44 & 32.6 & 91 & 67.4 & 135 & 100 & & \\
\hline
\end{tabular}

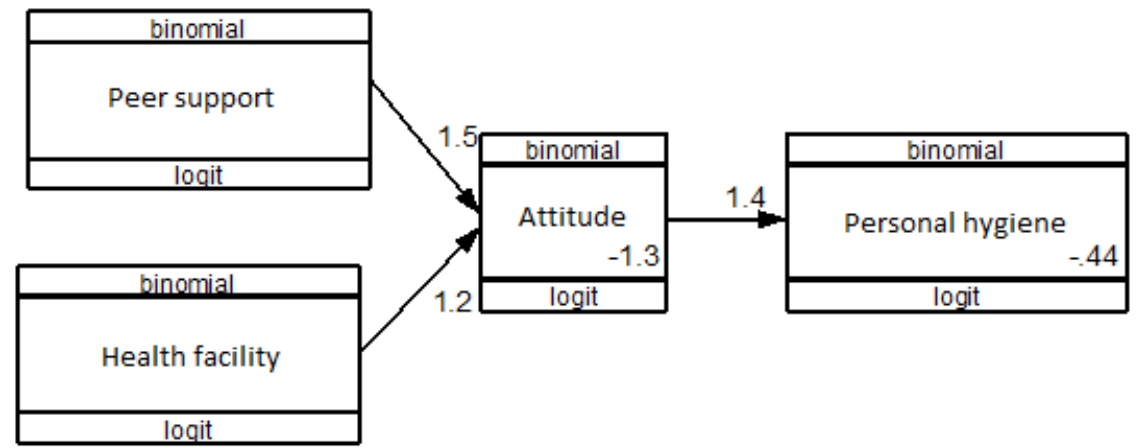

Figure 1. Structural model of path analysis

Table 3 The result of path analysis

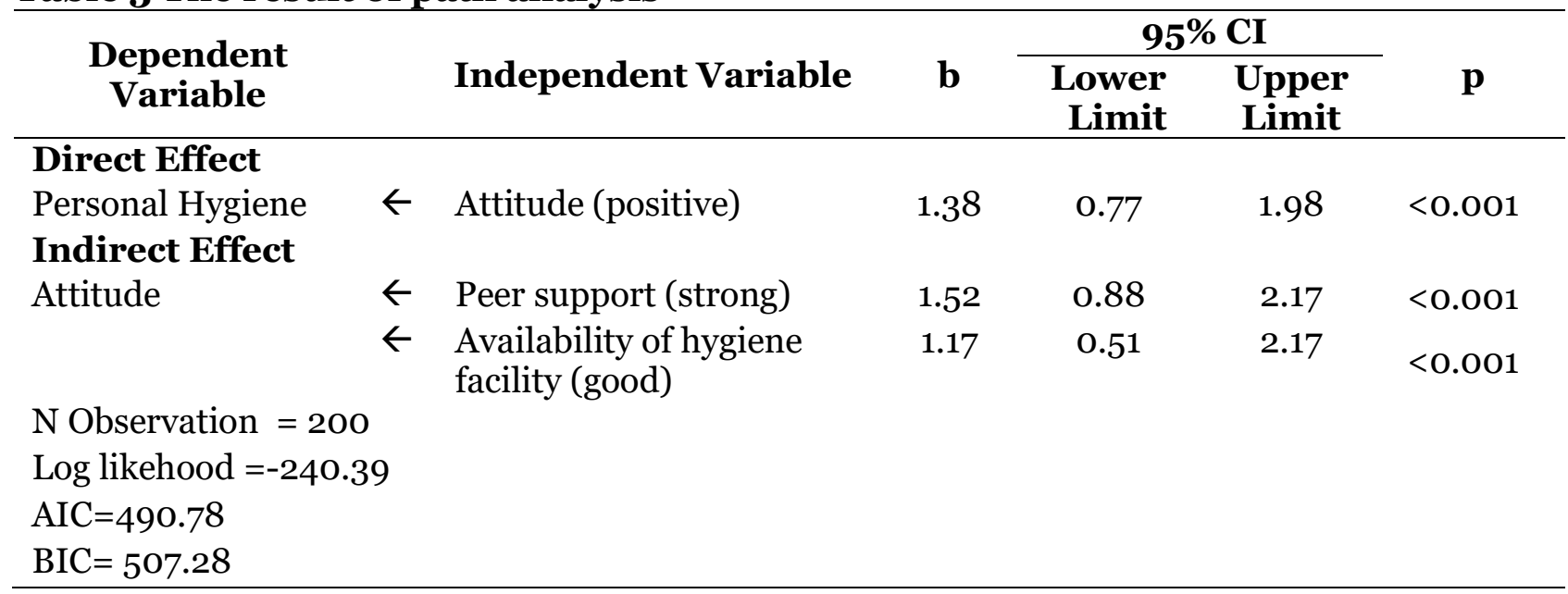




\section{DISCUSSION \\ 1. The correlation between attitude and personal hygiene}

The result showed that there was a significant correlation between attitude and personal hygiene in adolescents during menstruation. Personal hygiene during menstruation was affected by several factors such as the availability of personal hygiene facilities, socio-economic status namely family income, privacy, and comfort in maintaining hygiene during menstruation. Another factor such as the source of information about menstruation can be obtained from parents, school, friends, mass media, and attitude (Deshpande et al., 2018; Das, et al., 2015). Attitude is a feeling, predisposition, or set of beliefs that are relatively fixed to an object, a person, or a situation (Fehintola et al., 2017; Eslamimehr et al., 2017).

Attitude contains three components, namely cognition, emotion, and behavior. Adolescent who has a positive attitude in personal hygiene are more likely to maintain hygiene during menstruation. Knowledge, emotion, and good behavior improve one's attitude (Sulaeman, 2016; Vandana et al., 2016). Positive attitude that is related to personal hygiene occurs because they get information from the media (Nuraini and Ronoatmodjo, 2018). Anand et al. (2015) explains that poor attitude associated with personal hygiene, especially on the genitals, can cause vaginal discharge. It will affect serious illnesses such as cervical cancer, tumor, and pelvic inflammatory disease.

Another opinion states that attitude is the thought and feeling that encourage someone to behave, whether someone likes or dislikes something. Supporting factor or possible condition is needed to actualize the attitude into a real act, such as facility (Fehintola et al., 2017; Alam et al., 2017; Triwibowo and Pusphandani, 2015). This is in accordance with this study which shows that a positive attitude related to personal hygiene during menstruation in female adolescent is affected by the availability of personal hygiene facilities.

\section{The correlation between peer support and personal hygiene}

Based on the result of this study, there was a significant correlation between peer support and personal hygiene. The social environment of the adolescents will have a very big effect on adolescent attitude and behavior. During adolescence, an individual begins to spend more time with peers because peers have a very meaningful role for adolescents. Friends are the initial stage in adolescent association. Peers get main priority attention over family because they are considered to give more understanding, support, and shelter (Fehintola et al., 2017; Tiwari et al., 2018)

Adolescents can easily share their feelings or difficulties with their peers. Friends become one of the factors related to personal hygiene during menstruation. They are always ready to listen the problems due to the same fate. Besides, training related to personal hygiene during menstruation, especially for disabilities, is also very necessary (Wilbur et al., 2019). The development of adolescent social life is characterized by increasing influence of peers in life. Most of adolescent time is spent by doing social interactions with peers (Upashe et al., 2015).

\section{The correlation between the availa- bility of personal hygiene facilities and personal hygiene}

The result showed that there was a significant correlation between the availability of personal hygiene facilities and personal hygiene.

The availability of personal hygiene facilities must be available at home or public environment (Nasir et al., 2016). One of the sanitation facilities is the avai- 
lability of clean water. It can be maintained by a commitment and a program that is related to cleaning facilities in the community (Putri et al., 2017). The facilities and equipment are provided to support the goal of personal hygiene during menstruation (Das et al., 2015; Thakre et al., 2011).

The examples of the need for sanitary facilities during menstruation are sanitary napkin that is used during menstruation, clean water that is used as needed, a place to clean or toilet, soap or cleaning fluid, a place to throw the garbage (Das et al., 2017; Fehintola et al., 2017; Triwibowo and Pusphandani, 2015). Sivakami et al. (2019) also explain that the availability of personal hygiene facilities can improve good personal hygiene. The result of the study showed that the availability of poor personal hygiene facilities had 0.57 times more likely for having good personal hygiene.

\section{AUTHOR CONTRIBUTION}

Kunaryanti was the main researcher who collected and processed the data of the study. Uki Retno Budihastuti examined the conceptual framework and method of the study. Yulia Lanti Retno Dewi examined the result of the study.

\section{FUNDING AND SPONSORSHIP}

This study used personal funds from the main researcher.

\section{CONFLICT OF INTEREST}

There was no conflict of interest in the study.

\section{ACKNOWLEDGEMENT}

We give the best gratitude to the part of Senior and Vocational High Schol in Sragen for helping us to conduct this study. We also give the gratitude to all the female adolescents who have been willing and participated to become the subjects of the study.

\section{REFERENCE}

Anand E, Singh J, Unisa S (2015). Menstrual hygiene practices and its association with reproductive tract infections and abnormal vaginal discharge among women in India. Sexual \& Reproductive Healthcare, 6 (2015) 249-254 Retrieved from http://dx.doi.org/10.1016/j.srhc.2015.06.001

Alam MU, Luby SP, Halder AK, Islam K, Opel A, Shoab AK et al (2016). Menstrual hygiene management among Bangladeshi adolescent schoolgirls and risk factors affecting school absence: results from a cross-sectional survey. BMJ Open, 7: e015508. doi: 10.1136/bmjopen-2016-015508.

Das P, Baker KK, Dutta A, Swain T, Sahoo S, Das BS, Mishra PR (2015). Menstrual hygiene practices, WASH access and the risk of urogenital infection in women from Odisha, India. PloS ONE, 10(6), e0130777. Retrieved from https://doi.org/10.1371/journal.pone.0130777.

Deshpande TN, Patil SS, Gharai SB, Patil SR, Durgawale PM (2018). Menstrual hygiene among adolescent girls A study from slum area. J Family Med Prim Care. 7(6): 1439-1445. doi: 10.4103/jfmpc.jfmpc_80_18.

Eijk AM, Sivakami M, Thakkar MB, Bauman A, Laserson KF, Coates $\mathrm{S}$ et al (2016). Menstrual hygiene management among adolescent girls in India: asystematic review and meta-analysis. BMJ Open, 6:e010290. doi:10.1136/bmjopen-2015-010290.

Eslamimehr F, Rakhshani F, Ramezan Khani A, Khodakarim S (2017). The examination of the effectiveness of an educational intervention based on the 
Planned Behavior Theory on improving pubertal health behavior in female high school students. Int $\mathrm{J}$ Pediatri, 5(9): 5643-5654. doi: 10.22038/ijp.2017.24027.2028.

Fehintola FO, Fehintola AO, Aremu AO, Idowu A, Ogunlaja OA, Ogunlaja I P (2017). Assessment of knowledge, attitude and practice about menstruation and menstrual hygiene among secondary high school girls in Ogbomoso, Oyo state, Nigeria. Int J Reprod Contracept Obstet Gynecol, 6(5): 1726-1732. Retrieved from http://dx.doi.org/10.18203/2320-1770.ijrcog20171932

Geethu C, Paul EP, Thomas JE, Pullan CS, Hemalatha S, Sivakumar T (2017). Appraisal of menstrual hygiene management among women in a rural setting: a prospective study. Int $\mathrm{J}$ Community Med Public Health, 3(8): 2191-2196. Retrieved from http://dx.doi.org/10.18203/23946040.ijcmph20162569

Nasir S, Murti B, Suryani N (2016). Path analysis on the association between predisposing, enabling, and forcing factors, and house sanitation in Bengkulu, Sumatera. J Health Promot Behav, 1(3): 190-200 Retrieved from https://doi.org/10.26911/thejhpb.201 6.01.03.06.

Nuraini A, Ronoatmodjo S (2018). The effectiveness of comic as learning media to enhanceknowledge of menarche and menstruation among female students in Yogyakarta. J Health Promot Behav, 3(4): 257-262. Retrieved from https://doi.org/10.26911/thejhpb.2018.03.04.05.

Putri A, Joebagio H, Indarto D (2017). Community Participation in sanitation program, Surakarta. J Health Promot Behav, 2(3): 257-271. Retri- eved from https://doi.org/thejhpb.2016.02.03.06.

Sulaeman S (2016). Pembelajaran model dan teori perilaku kesehatan konsep dan aplikasi. Surakarta: UNS Press.

Sumpter C, Torondel B (2013). A systematic review of the health and social effects of menstrual hygiene management. PloS ONE, 8(4), e62004. Retrieved from https://doi.org/10.1371/journal.pone.0062004.

Sivakami M, Eijk AM, Thakur H, Kakade N, Patil C, Shinde S, et al. (2019). Effect of menstruation on girls and their schooling, and facilitators of menstrual hygiene management in schools: surveys in Government Schools in Three States in India, 2015. J Glob Health, 9 (1): 010408. doi: 10.7189/jogh.09.010408

Thakre SB, Thakre SS, Reddy M, Rathi N, Pathak K, Ughade S (2011). Menstrual hygiene: knowledge and practice among adolescent school girls of Saoner, Nagpur district. Journal of clinical and diagnostic Research, 5(5): 1027-1033. Retrieved from http://dx.doi.org/10.1155/2016/1056235

Tiwari A, Ekka IJ, Thakur R (2018). Assessment of knowledge and practices regarding menstrual hygiene among adolescent girls of Government higher secondary school, station Murhipar, Rajnandgaon (CG). Int J Community Med Public Health, 5(4), 1335-1338. Retrieved from http://dx.doi.org/10.18203/2394-6040.ijcmph20180973

Triwibowo C, Pusphandani M (2015). Pengantar dasar ilmu kesehatan masyarakat. Yogyakarta: Nuha Medika.

Upashe SP, Tekelab T, Mekonnen J (2015). Assessment of knowledge and practice of menstrual hygiene among high school girls in Western Ethiopia. BMC women's health, 15(1), 84. Retrieved 
from https://doi.org/10.1186/s12905015-0245-7.

Vandana V, Simarjeet K, Amandeep K (2016). Assessment of knowledge of adolescent school going girls regarding menstruation and menstrual hygiene. IJAR, 2(9): 240-246. Retrieved from http://www.allresearchjournal.com.
Wilbur J, Torondel B, Hameed S, Mahon T, Kuper H (2019). Systematic reviewof menstrual hygiene management requirements, its barriers and strategies for disabled people. PLoS ONE 14(2): e0210974. Retrieved from https://doi.org/10.1371/journal.pone.02109$74 \mathrm{E}$. 